\title{
Fintech, Base of the Pyramid Entrepreneurs and Social Value Creation
}

\author{
Ahmad Arslan \\ Associate Professor, \\ Department of Marketing, \\ Management and International Business, \\ Oulu Business School, \\ University of Oulu, Finland. \\ ahmad.arslan@oulu.fi
}

\author{
Bonnie Buchanan \\ Head of Department of Finance and Accounting \\ Professor of Finance, \\ Department of Finance and Accounting, \\ Surrey Business School, University of Surrey, \\ United Kingdom. \\ b.buchanan@surrey.ac.uk \\ Samppa Kamara \\ Doctoral Student, \\ Department of Marketing, \\ Management and International Business, \\ Oulu Business School, \\ University of Oulu, \\ Finland. \\ samppa.kamara@oulu.fi
}

\author{
Nasib Al Nabulsi \\ PhD Graduate, Hanken School of Economics, Vaasa, Finland. \\ Independent Post-doctoral Researcher, \\ Vaasa, Finland. \\ nasib.nabulsi@gmail.com
}

This is an authors' accepted manuscript (AAM) version of the paper accepted to be published in "Journal of Small Business \& Enterprise Development" (Emerald). Kindly, cite the paper as:

Arslan, A., Buchanan, B., Kamara, S., \& Al-Nabulsi, N. (2021). "Fintech, Base of the Pyramid Entrepreneurs and Social Value Creation", Journal of Small Business \& Enterprise

Development, Available online at https://doi.org/10.1108/JSBED-10-2020-0370 


\title{
Fintech, Base of the Pyramid Entrepreneurs and Social Value Creation
}

\begin{abstract}
Purpose: Fintech is having a profound impact in Sub-Saharan Africa (SSA) because it offers more financial inclusion. In this paper, we examine the interrelationship of Fintech, base of the pyramid (BOP) entrepreneurs, and social value creation in Sierra Leone.

Design/methodology/approach: The current paper uses a qualitative research design with openended, in-depth interviews as the main data sources. We interview the respondents from the Sierra Leone Fintech Association and four BOP entrepreneurs operating in different sectors.

Findings: We find that Fintech services, specifically mobile money, play a significant role in reducing uncertainty surrounding business operations. FinTech offers growth possibilities for BOP entrepreneurs, creating social value by providing transactional security, convenience, and reducing cash robberies. Fintech also contributes to social value by enhancing BOP entrepreneurs and consumer development skills.

Research Implications: Our study highlights the importance of context-specific theorization when analyzing the interlinkage between BOP entrepreneurship, social value creation, and Fintech. For example, the possibility of safety from street robbery may not appear to be part of social value creation by a technological development like Fintech. However, in Sierra Leone, which has experienced both a civil war and an Ebola outbreak, insecurity has been one of the biggest concerns expressed by BOP entrepreneurs. Hence, scholars need to incorporate contextual elements of risk, uncertainty, and volatility while theorizing on Fintech's application in BOP contexts.

Practical Implications: A key managerial implication relates to micro-firm entrepreneurs and information specific benefits. Fintech offers entrepreneurs regular contact with customers to evaluate their purchasing patterns and emerging needs. Fintech offers BOP entrepreneurs a possibility to further develop their technological skills. From a policy perspective, our study highlights the importance of regulating Fintech charges so that the affordability is increased, leading to greater BOP entrepreneur usage.

Originality: Our paper is one of the first studies that specifically focuses on BOP entrepreneurship and social value creation by Fintech services in a SSA context. It is also one of the few studies that incorporates views from both entrepreneurs and a country's leading Fintech association. Finally, we specifically focus on BOP micro-entrepreneurs.
\end{abstract}

Keywords: Base of Pyramid (BOP), Fintech, Sierra Leone, Social Value, Entrepreneurship

JEL Codes: G29, L31, M13, M16, O32, O33, O35 


\section{Introduction}

FinTech ${ }^{1}$ has rapidly disrupted and innovated the global financial system by creating new business models, revenue streams, and investment opportunities. Various Fintech categories include (but are not limited to) cryptocurrencies, blockchain, peer-to-peer (P2P) lending, artificial intelligence platforms, insurtech, crowdfunding, and mobile payments systems (Chen et al., 2019; Das, 2019; Liu et al., 2020). In 2019, Fintech attracted US\$135.7 billion in global investment, more than double the amount in 2017 (US\$50.8 billion). In 2020, there were 2,953 Fintech startups worldwide (Statista, 2020).

The surge in Fintech startups and investment is viewed as a reaction to the 2008 global financial crisis (GFC), when trust in the banking system dissipated. Post GFC, the rise of FinTech is also attributable to more volatile bank performance, higher regulatory constraints (e.g., Basel III), low interest rates, an abundance of global capital flows chasing yield, changing customer expectations, and the mass adoption of smartphones and cheaper data processing. (Buchanan and Cao, 2018). The increased use of blockchain, artificial intelligence, cloud computing, and big data have all created an affordable infrastructure to spur Fintech innovation (Buchanan and Cao, 2018; Das, 2019; Palmié et al., 2020).

FinTech has impacted both developed and emerging markets by providing opportunities for approximately 1.7 billion adults who are "unbanked."2 It also targets a funding gap of more than USD\$2 trillion for small and medium-sized enterprises (SMEs) in emerging markets. Fintech has the potential to reduce information asymmetry, mitigate risk, and allocate capital more efficiently. Das (2019) acknowledges Fintech is characterized by technological change in three areas: (a) raising capital (b) allocating capital, and (c) transferring capital. Lee and Teo (2015) state that most successful Fintech innovations demonstrate the LASIC principle (or low profit margin, asset light, scalable, innovative and compliance).

Mobile payment technology ${ }^{3}$ efficiently transfers capital and has proved most successful in countries with fragile institutional structures, including the banking system (Yermack, 2018). It has included millions of new customers in India, China, and Africa and has decreased cross-border

\footnotetext{
${ }^{1}$ The emerging Fintech literature has a variety of definitions, but in this paper, we assume the Financial Stability Board (2017) definition: "FinTech is technologically enabled financial innovation that could result in new business models, applications, processes, products, or services with an associated material effect on financial markets and institutions and the provision of financial services."

${ }^{2}$ By "unbanked", we mean individuals who do not have access to some form of a traditional bank account.

${ }^{3}$ This can be via the internet or mobile phones.
} 
remittance costs and increased financial inclusion (Da Silva, 2018) ${ }^{4}$. Indeed, previous research shows that mobile money adoption in Africa is dominated by people who do not own 'formal' and 'informal' accounts (Ashenafi et al., 2016). For example, only one-third of people in Sub-Saharan Africa (hereafter denoted SSA) have a bank account. Financial inclusion has been boosted by mobile money innovations in SSA, with 21 percent of adults having a mobile money account, the most for any region in the world (Demirguç-Kunt et al., 2017). More than half of the 282 mobile money services operating worldwide are located in the SSA region ${ }^{5}$. It is estimated that by 2024 the digital payments market will reach US\$8.2 trillion (Statista, 2020).

Entrepreneurship provides a viable solution to extreme poverty (Sutter et al., 2019; Kimmit et al., 2019). Yet, the pace of fintech adoption differs across developed and developing economies (Frost, 2020). For example, a lack of access to traditional banking services has long been a reality for the base of the pyramid (hereafter known as BOP) entrepreneurs (Surie, 2017; Leposky et al., 2020). Several studies address business issues like frugal innovation, social enterprises, technology, local entrepreneur use, and product marketing strategies in BOP markets in Africa, Asia, and Latin America (Hall et al., 2012; 2014; Surie, 2017; Makina, 2019; Onsongo, 2019).

Even though SSA has lagged the rest of the world in terms of economic development, some countries in the region are now considered Fintech leaders. Significant research attention has been devoted to the success of Fintech firms like M-Pesa (Chandy and Narasimhan, 2011; Kemuma et al., 2015; Onsongo, 2019). Yet, Beck, et al., (2015) and Yermack (2018) recognize that MPesa tends to be an anomaly. Moreover, countries like Kenya, South Africa, Nigeria have received far more attention than other SSA economies (Maino et al., 2019). It should further be noted that most BOP entrepreneurs operate in sectors like agriculture, fishing, and small retail trading, where the potential for creating social value is very high. Yet, there is a dearth of literature on Fintech and these sectors.

In this paper, we draw the Fintech, BOP entrepreneurship, and social value creation literature streams together. To the best of our knowledge this paper is one of the first to specifically focus on social value created by Fintech for BOP entrepreneurs in a SSA context (particularly Sierra Leone). Furthermore, our focus specifically targets entrepreneurs managing micro firms (less than

\footnotetext{
${ }^{4}$ Financial inclusion can be broadly defined as ' $a$ state in which all working-age adults, including those currently excluded by the financial system, have effective access to the following financial services provided by formal institutions: credit, savings and current accounts, payments, and insurance' (GPFI, 2016).

5 "Orange Mobile Money take up in Central Africa may double in 2018", Bloomberg.
} 
10 employees). By doing so, we aim to avoid generalizations made in the literature where micro firms are analyzed alongside SMEs (which in many cases have a different customer and resource base).

The Sierra Leone Fintech ecosystem is an interesting laboratory to examine how BOP entrepreneurs exhibit agility when responding to uncertainty. Sierra Leone is less developed than other SSA nations and is underserved by the traditional banking system. Seventy percent of the population live below the poverty line and there is high unemployment. Sierra Leone experienced a civil war during 1991-2002, an event that impacted all spheres of life, including entrepreneurship (Collier and Duponchel, 2013).

However, when it comes to Fintech development, Sierra Leone has demonstrated an early mover advantage relative to other SSA nations. Indeed, the 2014-2015 Ebola outbreak in Sierra Leone was a catalyst for swift Fintech adoption. For example, Sierra Leone became the first country to allow citizens to vote in elections using blockchain technology. ${ }^{6}$ Sierra Leone is the second African country (after Kenya) to adopt a regulatory sandbox for Fintech development. Like many other countries, Sierra Leone is moving to a less cash-dependent economy through mobile phone payments. This has also helped overcome vast distances between bank branches and home, as well as reducing corruption. The view about going cashless has been reinforced during the recent COVID pandemic. Our findings can guide researchers by showing how Fintech can yield a positive social change in a post-pandemic environment.

Our empirical research design is based on qualitative case studies where interviews are undertaken with BOP entrepreneurs as well as with representatives from the Sierra Leone Fintech Association (hereafter known as SLFINTECH). We find that social value is created through less corruption, fewer cash robberies, better transactional security, affordability, and accessibility. Social value is also created through improved skills development, further reducing uncertainty.

We make several contributions to the literature. Social value creation as a concept has received much attention in recent years. Social value creation is defined as "an activity that leads to the realization of any of the three core values of development: sustenance, self-esteem, and freedom from servitude" (Todoro and Smith, 2012). However, the focus has been mostly on the activities of foreign (primarily Western) multinationals operating in developing and emerging economies (Leposky et al., 2020). We find that all the interviewees in our study experience sustenance, self-

\footnotetext{
${ }^{6}$ (Business Insider, March 14, 2018).
} 
esteem, and greater independence in their firm operations. In fact, we document that better trust is established between BOP entrepreneurs and banks via Fintech usage. Secondly, our paper is one of the few studies that incorporates both sides' views, rather than focusing solely on either entrepreneurs or Fintech firms. Finally, our paper's key contribution comes from a focus on social value creation, as we link Fintech's role for BOP entrepreneurs to this specific topic. A focus on social value creation is important because it highlights services to a disadvantaged section of the population, who previously could not access traditional financial services (De Silva et al., 2019; Onsongo, 2019; Leposky et al., 2020).

Our paper complements Onsongo (2019) by undertaking the analysis in the under-researched SSA context of Sierra Leone. Like Onsongo (2019), we consider mobile monetary payments as a social innovation. However, Onsongo (2019) focuses on M-Pesa, mainly from the provider perspective, whereas we analyze mobile phone payments as a social innovation from the perspective of both the entrepreneurs and SLFINTECH. Like Yao et al. (2018), we find that technological innovation is driven by demand and drives the development of a country's financial industry. However, we focus on a different market that has an early mover advantage as well as micro-enterprises (as opposed to small businesses in general).

The rest of the paper is organized as follows. The next section presents a literature review followed by a contextual overview of SSA Fintech and Sierra Leone. We then discuss research methodology, followed by our findings. The paper concludes with a discussion of implications.

\section{Literature Review}

In a Fintech literature synthesis, Gomber et al. (2018) propose a three-dimensional structure to identify untapped territories. The first dimension focuses on interactions between financial intermediaries and include business-to-customers and business-to-business models offering financial services. Fintech firm functions along this dimension can further be divided into six areas: finance, investments, money, payments, insurance and advice. The second dimension refers to emerging technologies such as blockchain and big data analysis. The third dimension includes companies such as start-ups and IT firms and traditional financial institutions. Other studies link technology usage with financial services (e.g., Berger et al., 1999).

Alt et al. (2018) point out that the Fintech industry has grown from a physical media presence (1500-1860) to analog technologies (1860-1960) to more digital technologies (1960s 
onwards). As Fintech evolves, it is influenced by new market participants (Zetzsche et al., 2019), and foundational technologies that provide viable customer acquisition costs (Arner et al., 2020). Similarly, studies identify technological change in the banking industry and investment to represent progress in Fintech (Thakor, 2020; Gomber et al., 2018; Lee and Shin, 2018; Romānova and Kudinska, 2016).

Vives (2017) investigates the impact of FinTech on efficiency, banking market structures, and financial stability, detailing that the banking industry benefits from Fintech's lower cost of intermediation and wider financial inclusion. Reasons for financial exclusion include lack of funds and traditional banking practice rules (Kamran and Uusitalo, 2019), unmet demand by traditional banks (Frost, 2020) and long physical distances between bank branch locations and home (Demirguç-Kunt et al., 2017; Frost, 2020). Other factors, such as lack of proper documentation and educational level, compound financial exclusion problems (Makina, 2019; Das and Drine, 2020). However, Watkins et al. (2017) and Maino et al. (2019) indicate established BOP entrepreneurs have the potential to integrate Fintech applications (specifically mobile money) and circumvent these barriers and potentially create social value.

In the mobile banking literature (Dewan, 2010; Yousafzai, 2012; Shaikh and Karjaluoto, 2015; Tam and Oliveira, 2017; Alkhowaiter, 2020), there is a consensus that smartphone demand in both developed and developing markets continue to have a profound effect on mobile banking services. As Frost (2020) posits, new fintech providers have established a strong foothold in mobile payments, especially for the retail customers. For example, mobile money facilitates money transfer, mobile payments, Quick Response (QR) and SMS technology (Da-Silva, 2018; Onsongo, 2019). In 2019, 5.2 billion people subscribed to mobile services, accounting for 67 per cent of the world's population (GSMA, 2020). Also, mobile service technology generated $\$ 4.1$ trillion in economic value, accounting for 4.7 per cent of global GDP (GSMA, 2020). Thus, the banking industry's evolution from local branches to internet banking (or place centric) and mobile banking (or equipment centric) has yielded benefits of shorter customers queues and wait-time (Tam and Oliveira, 2017). Companies and industries have been transformed by disruptive innovations (Palmié et al., 2020), resulting in a higher comfort level and lower costs (Teja, 2017). Furthermore, the BOP population segment uses mobile Fintech services to avoid paying high fees and financial exclusion (Maurer, 2012; Buchanan and Cao, 2018). 
Despite research that examines SSA-specific mobile money adoption (Koomson et al., 2021; Coffie et al., 2020; Kabbiri et al., 2018; Kanyam et al., 2017; Mothobi and Grzybowski, 2017), there is a lack of research specifically focusing on entrepreneurship and social value creation by Fintech in a SSA context. Asongu et al. (2018) examine mobile phone governance for doing business in SSA, and find that Fintech services availability strengthens entrepreneurship in developing countries. Similarly, in identifying the determinants of Fintech payment services diffusion in SSA, Coffie et al. (2020) focus specifically on SMEs firms using data solely from Association of Ghanaian Industries (AGI). Instead, our study includes both micro enterprise entrepreneurs and the country's Fintech association perspectives, rather than focusing solely on entrepreneurs or Fintech firms.

\section{Fintech in SSA: Contextual Overview of Sierra Leone}

According to recent statistics, there is a 74 per cent mobile phone penetration rate in SSA (GSMA, 2019). Due to its growth potential, SSA represents an exciting and attractive market for Fintech firms (Maino et al., 2019), and the BOP segment is a major driver of global trade and growth. Agricultural entrepreneurs and small farms are considered important income sources for the BOP sector in the SSA region, with the agricultural industry accounting for more than 15 per cent of GDP (OECD/FAO, 2016), and more than half of the population employed in this sector (Hilson, 2016). Thus, Fintech applications, such as mobile money payments, can create social value and increase agricultural commercialization by facilitating more straightforward transactions between producers and suppliers of agricultural products. In SSA such facilitation is crucial because individuals and small businesses can potentially save between 80 and 90 per cent in costs compared to traditional financial services (Manyika et al., 2016). Thus, producers may get a better price for products than using traditional intermediaries, which tends to be detrimental to the farmer (Welsh, 1997; Lyson, 2012).

Prior studies find that farmers who use mobile money services have a higher income than those who do not use them (Kikulwe et al., 2014; Baumüller, 2018). Fishing is another important sector that plays an essential role in staple food provision in SSA (Eicher and Baker, 1982). Fishing is directly linked to BOP entrepreneurship as it offers employment options for both men and women (Anderson and Obeng, 2017). Although there is a dearth of research on the link between fishing entrepreneurship and Fintech in a SSA BOP context, Boateng and Sarpong (2019) highlight 
mobile payment user's positive impacts. A similar conclusion is valid for other BOP entrepreneurs (micro firms) operating in different sectors, as Fintech and mobile services offer ease of financial management and can circumvent other operational barriers (Kanyam et al., 2017; Mothobi and Grzybowski, 2017; Kabbiri et al., 2018). Gölgeci et al. (2020) suggest that entrepreneurs tend to display a specific kind of agility in an uncertain context. One example of agility is Fintech which has a potential to contribute to the resilience and adroitness of BOP entrepreneurs in Sierra Leone regarding operations and social value creation.

Das and Drine (2020) measure the technological gap between African nations and emerging economies. They recognize Africa's poor infrastructure, relatively poor business environment, and lack of human development as significant technological development barriers. Low volume activities stifle many industries in Africa. Das and Drine (2020) provide evidence that economic development is not impossible, but investment in technology must address these shortcomings. In this regard, legal origin matters (Yermack, 2018). According to Yermack (2018), countries with a common law legal origin offer better financial inclusion compared to civil lawbased countries. Sierra Leone has a common law heritage. Even so, Sierra Leone scores below other SSA common law-based countries.

Sierra Leone clearly fits the BOP criteria. The country’s GDP per capita is US\$1600, and seventy percent of Sierra Leone's population lives below the poverty line. Unemployment is very high, and nearly half of the working-age population engages in subsistence agriculture. Compounding these economic difficulties is the fact that Sierra Leone has been exposed to falling global commodity prices.

Pervasive corruption and the risk of fraud have been deterrents to foreign direct investment in Sierra Leone. The SSA region scores poorly on the Transparency International Corruption Perception Index (CPI). The region averages a CPI score of 32, with Sierra Leone scoring $33^{7}$. In terms of CPI rankings, Sierra Leone is ranked $119^{\text {th }}$ out of 198 countries but has moved up 10 places in the last decade. In terms of the global corruption barometer, 52 percent of Sierra Leone public service users admit to bribe payments, and $43 \%$ of respondents think corruption has increased in the country. On a scale of 0 to 100 (with 100 being the best), Sierra Leone scores 47 for ease of doing business. More positively, on average, it takes 8 days to start a new business in

\footnotetext{
${ }^{7}$ A perfect score is 100 , and the worst, 0 .
} 
Sierra Leone, compared with a 28-day average for other common-law SSA countries (Yermack, 2018).

Historically, most of the population has been unbanked, and there have been numerous hurdles to Sierra Leone banking access. Remittance costs to other countries are expensive, with Sierra Leone averaging 8.3 percent. The banking sector has also faced challenges in the form of currency fluctuations and a low supply of financial products like credit, insurance, and savings products (Didenko, 2017).

The largest impediment to more rapid Fintech growth in SSA appears to be the electrical and communications infrastructure. Sierra Leone has electricity and internet penetration rate of 9 percent and 11.7 percent, respectively, compared with an average of 46.2 percent and 38.5 percent for common-law SSA countries (Yermack, 2018). Only 6.8 percent of the Sierra Leone rural population has access to electricity. This is also one reason bitcoin mining has not been extensive in Sierra Leone, because cryptocurrency mining consumes enormous amounts of electricity.

Fintech growth in Sierra Leone has largely been in mobile money, blockchain, and RegTech. Sixty percent of the population is under 25 years of age. This is largely a result of the Sierra Leone civil war between 1991 and 2002. However, the youth-based population has also been very receptive to innovation, particularly in mobile phones. For every 100 inhabitants, there are 102 mobile phone subscriptions. In response to the 2014-2015 Ebola outbreak (CIA World Factbook. 2020), the government turned to mobile wallets to help money circulate throughout the economy.

Sierra Leone was the first country to let citizens vote in elections using blockchain (Business Insider, March 14, 2018). Blockchain technology was used to verify votes to reduce corruption in the election process. Agora, a Swiss blockchain company, provided the service to Sierra Leone's Western District, the nation's most populous area and includes its capital, Freetown. The platform had limited observer status to help verify the accuracy of voting in the first round of a presidential election in Sierra Leone.

Traditionally, if a potential customer wanted to open a bank account in Sierra Leone, (s)he might be asked for ten identity documents, and then it would take two weeks to open the account. ${ }^{8}$. The Sierra Leone government and Kiva (a US nonprofit microfinance company) partnered to address this problem and launched a blockchain and decentralized identity implementation to

\footnotetext{
8 “Sierra Leone launches blockchain-based identity implementation platform”, The Paypers, September 6, 2019.
} 
overcome these barriers to access. Finally, SLFINTECH was founded in 2016 as part of the 20172020 National Strategy for Financial Inclusion. SSA countries have tended to take a hands-off approach to Fintech regulation. However, after Kenya, Sierra Leone is the second African country to launch a Fintech regulatory sandbox. SLFINTECH also runs an annual Fintech Challenge.

\section{Research methodology}

We use a qualitative research approach because of its potential to offer an in-depth analysis in management studies (Lee and Lee, 1999; Birkinshaw et al., 2011). We draw on Patton (2002) to describe and explain the process of data collection and analysis. Since there is a dearth of empirical research on BOP and Fintech in SSA (particularly Sierra Leone), it is important to ensure that the empirical data are trustworthy due to its exploratory nature. The use of an holistic approach is necessary as there is a limited possibility of replicating earlier research in this specific framework (Cazurra et al., 2016). Thus, we implement a "qualitative rigor" approach to highlight and offer legitimacy to raw elements inside unknown categories (Reuber et al., 2017; Eisenhardt, 2020). Previous management research indicates that inductive qualitative research is adequate to produce in-depth insights knowledge from small samples (Chetty, 1996; Lee and Lee, 1999; Stenbacka, 2001; Arslan et al., 2020), as it enables researchers to establish reliable linkages between research and findings (Patton, 2002). In the following sub-section, we provide a comprehensive background to the research setting.

\subsection{Research setting and background on case firms}

Specific case selection in qualitative management research should be driven by the opportunity to better understand the overall research objective (Chetty, 1996; Lee and Lee, 1999; Baxter and Jack, 2008; Arslan et al., 2020). The case study approach has been referred to as a useful tool in an African framework (Arslan et al., 2020). Small-scale trading and entrepreneurial activities are regarded as a catalyst for economic development in countries such as Sierra Leone (Kamara, 2008). The five case firms selected for this study are carefully sampled due to their

dynamic business operations covering diverse economic sectors ranging from agriculture, cosmetics, fishing, and manufacturing industries.

Given our focus on Fintech, we select firms based on the following criteria: (1) the firm must have a minimum of two years' experience integrating Fintech services and products in their 
business operations and (2) all the case firms are micro-enterprises (less than 10 employees). This aspect is important for the sake of comparative analysis. It is also because such firms tend to be representative of most entrepreneurs operating in a BOP context, rather than SMEs that, in many cases, tend to have more resources and may not face the same problems concerning financial services. SLFINTECH is selected due to its supporting role in the Sierra Leone Fintech ecosystem. Thus, the selected cases represent both the micro firm and industry association's point of view. We have not revealed the names of interviewees and case firms in order to maintain their anonymity.

The first case firm, "A", is a contract manufacturing firm that produces home and office furniture. Firm A was established in 2015 and currently employs six individuals across two offices in Freetown (the capital). Since its launch, firm A is one of the few micro-firms in Sierra Leone that is currently benefiting from Chinese and Sierra Leone trade relations, as over 90 per cent of its raw materials are imported from China. The second case firm, " $\mathrm{B}$ " is a cosmetic products provider established in 2014. Firm B is a family-owned business and currently employs two individuals. Since 2014, firm B has grown to be one of the most reputable small-scale providers of cosmetic products in the western part of Freetown. The third case firm, "C", was also founded in 2014, and has become one of the most recognized small-scale fishing firms in the eastern part of Freetown. At the time of the interview, firm C employed six individuals. The fourth case firm, "D", was founded in 2018. Firm D's business model is based on indigenous agricultural food

products that target a demographic market of infant children, pregnant women, and lactating mothers. At the time of interview, firm D employed eight individuals. The fifth case firm, SLFINTECH, was founded in 2016 as part of the 2017-2020 National Strategy for Financial Inclusion. SLFINTECH acts as an independent association responsible for supporting and developing Sierra Leone's local Fintech ecosystem. It also runs an annual Fintech Challenge. At the time of the interview, SLFINTECH employed eight individuals and operates jointly with the Bank of Sierra Leone and the United Nation Capital Development Fund (UNCDF) to encourage financing solutions among small businesses.

\subsection{Data collection}

Following (Lee and Lee, 1999) and (Patton, 2002), we collect raw data through semistructured interviews on the basis that it provides an holistic overview and allows us to obtain 
insightful and real-time accounts. Moreover, the flexibility of using the semi-structured interview approach is that it may reveal information that is considered important to interview participants but might not have originally been a pertinent idea to the interviewer (Eisenhardt, 1989; Lee and Lee, 1999). In summary, a total of 6 interviews were conducted across 5 firms (one at each micro firm and two at SLFINTECH).

The interviews were conducted in English and carried out between February and March 20209. The micro-firms' interviews were conducted through Skype, whereas the interviews with SLFINTECH were conducted through Zoom. Three of the interviews with the case micro-firms took place while the interviewees were at their respective private offices across Freetown, whereas the remaining case firm interview took place at the interviewee's home. Both interviews with SLFINTECH participants took place at the company head office at 192 Kandeh Drive, Off Wilkinson Road, Freetown. The interviews were audio-recorded and automatically transcribed. Table 1 below offers a summary of the cases, interviewees' positions, and gender.

[Insert Table 1 about here]

Bearing in mind prior qualitative management research (Chetty, 1996; Eisenhardt, 1989; Lee and Lee 1999; Eisenhardt, 2020), we recognize that four case firms may provide sufficient data to analyze the role of Fintech services for entrepreneurs operating in the Sierra Leone BOP market. $^{10}$

Before each interview, we notified participants about our research focus. Like Lee and Lee (1999) and Eisenhardt (2020), the interviewer placed an emphasis on open discussion and the free flow of information. During the interview, participants were asked to reflect on the current state of Fintech services in Sierra Leone with the focus on perceived differences in comparison to traditional banking operations. Questions regarding FinTech and micro-firm adaptation were of a practical nature. ${ }^{11}$ Finally, we asked both the firms and SLFINTECH several questions about value creation in the BOP market in an open-ended way to understand their perspective and experience.

\subsection{Data analysis}

\footnotetext{
${ }^{9}$ Note that this is before many countries went into lockdown due to the COVID outbreak.

${ }^{10}$ Eisenhardt (1989) suggests a study of between 4 and 10 cases usually works well.

11 The questions and interview themes list are available upon request.
} 
To facilitate data analysis and make it more systematic, we use the NVIVO qualitative analysis software package. NVIVO is a software package for data management, coding, and retrieval. As this is primarily a qualitative study, we employ a "theoretical" thematic analysis approach to carefully examine our data based on two levels: (1) participants' experience on how FinTech contributes to social change and value creation and (2) Fintech practicalities for both the entrepreneurs and SLFINTECH managers. A "theoretical" thematic analysis makes more sense for this study due to the absence of prior valid hypotheses in previous studies that tackle the issue of Fintech and product marketing strategies in BOP markets. Initially, we analyze and compare each participant's experience and contribution to search for meaning and pattern that aligns across our data based on Patton's methodology (2002).

Subsequently, we identify as many viable potential themes or patterns as possible to retain an account of any possible linkage across each interviewee. After the data has been initially coded and gathered, we collect all the similar coded data to identify potential themes, to conceptualize a view of our research framework. Afterward, we embark on reviewing, defining, and naming themes to determine rigorously established themes appropriate for the research analysis.

In summary, we employ a qualitatively rigorous approach to provide legitimacy to the collected data, where each interview question aligns significantly towards analyzing the role of Fintech for entrepreneurs operating in the Sierra Leone BOP market. As a result, we continue to compare our data to provide a concise, coherent, and non-repetitive account (Patton, 2002; Braun and Clarke, 2008; Eisenhardt, 2020), and to ensure our interpretation resonates with the data. Our findings are presented in the next section.

\section{Findings}

\subsection{BOP Entrepreneurs' access to Fintech services}

Our study interviewees acknowledge that there is increasing access to finance to run dayto-day firm operations. Notably, while discussing how mobile money access has enhanced small business operations across Sierra Leone, the owner of firm B pointed out "today, [...] due to GTSIMPAY $Y^{12}$, I do not have to go to the bank to collect or deposit money. Until now, I could spend at least 1 hour in a bank queue and an extra 15 - 20 minutes with the cashier before I can leave the

\footnotetext{
${ }^{12}$ GT-SIMPAY is the first-ever phone banking service introduced in Sierra Leone. Its Overlay platform does not require the internet for activation and operation.
} 
bank". She stressed that "as a single mother with three children, it was not easy to look after them properly in the morning before sending them to school when I have to rush to the bank". However, she further noted that "... since I started using GT-SIMPAY two years ago, I have easy access to my finance ....... [So], to me as a mother and businesswoman, this is a big benefit".

Reinforcing firm B interviewee's opinion, the owner of firm A pointed out that "... we are dealing with client's money - most of the times, we used our clients' money when traveling to China to buy raw materials. [The opportunity for us] to have GT-SIMPAY that we can use in China without having to travel with a bag of money is a big plus to our business operation... with my mobile money card, I can deposit and withdraw money into my bank account, and also I can transfer money".

The owner of firm C further emphasized that "the opportunity for us to use GT-SIMPAY and Orange Money cards in our business has changed the way we operate". Specifically, he points out that "... we do not need to go to the market frequently to collect owing from our customers, [as] the majority of our customers are utilizing these cards to transfer money into our business account". Furthermore, he noted that the integration of Fintech mobile money into their business operation has "...enable me to create an excellent relationship with the bank through the chain of trust since there is an easy flow of money between the bank and me".

The firm D interviewee also cited that accessibility to Fintech mobile money cards continues to create a bond between some banks and small-scale entrepreneurs. The interviewee reiterated that "...some banks offer benefit [to entrepreneurs] ...... For me, as an entrepreneur, who always need bank support, that brings me closer to the bank". Furthermore, when discussing the value of mobile money, he pointed out that, "[as] we sell a majority of our goods mainly to village consumers and NGOs operating in the villages, we do not need to visit the village often anymore to collect owing, [majority of]our customers are using Orange Money, because of its simplicity".

\subsection{Fintech and Theft Protection for BOP Entrepreneurs}

The firm D interviewee pointed out that "to date, I feared for my life when traveling to the villages to collect owing. Because three years ago, I lost 2 million Leones ${ }^{13}$ as our (public) bus

\footnotetext{
${ }^{13}$ Based on currency converter, OANDA, this is equivalent to US\$203 (July 2, 2020) - or equivalent to half the average per capita GNP,
} 
was attacked when traveling from Koidu Town [Kono]to Freetown". While public bus attacks are frequent in deprived rural areas across Sierra Leone, when discussing the impact of mobile money on street robbery, the firm B interviewee pointed out that "...there are not many street boys and thieves outside the banks anymore. Before, as soon as they see you leaving the bank with a bag, they will follow you [...] I was a victim of street robbery twice at Siaka Steven Street, [Freetown, Sierra Leone]". Nevertheless, "today I do not need to worry about a robbery or how much money I have to withdraw from my account".

Similarly, the firm A interviewee added, "before mobile money; the unknown was a big issue for us - as we are dealing with client's monies. So, every time we had to come to the bank to withdraw money, we feared street robbers ...... Some entrepreneurs sometimes brought with them minders to dispel street boys that are always standing outside the banks". Firm $\mathrm{C}$ interviewee acknowledges that "the introduction of mobile money has had an impact on why street robbery is so rare today [...] it has revolutionized banks service delivery to us and the general public... consequently, reduce the fear we were facing when withdrawing money from the bank".

In terms of social change and value creation in Sierra Leone, one manager at SLFINTECH acknowledged "...most businesses are benefiting [from the integration of mobile money into their businesses], and the general public is gradually adopting electronic channels of payment". Specifically, he pointed out that "with mobile money, we have less cash, less crime [...] and a recent survey we carried out with the Bank of Sierra Leone shows that 8 out of 10 small scale entrepreneurs across Freetown have less cash at hand for day-to-day business operation compared to 6 years ago". The reason for this is that "mobile money is simple and offers entrepreneurs more flexibility to move money around easily".

Another SLFINTECH manager also acknowledged the benefits of mobile money in Sierra Leone. He elaborated, "since the government launched mobile money in 2015, there has been a huge impact of social change..... With the establishment of our association and the commitment from the Bank of Sierra Leone and partners organizations, we continue to facilitate, support, and provide clarity on mobile money services to small scale entrepreneurs, young Fintech innovators, and mobile agents across the country". For example, together with the Bank of Sierra Leone and the UN Capital Development Fund (UNCDF), "we continue to organize the Fintech challenge to render opportunity, increase awareness of mobile money, and give financial inclusion to all Sierra Leoneans". The manager further added that what is more appealing with mobile financial services 
in Sierra Leone is "we have one of the cheapest and affordable mobile money charge legislation in the Manor River Union".

\subsection{Public awareness of Fintech, Potential for Skills Development and Practicalities}

When discussing public awareness of Fintech products, specifically mobile money usage, the firm D interviewee recognized, "...with the increasing access to high-end phones, Sierra Leoneans are seeking ways to integrate mobile money into their daily lives. [...] to pay for electricity bills, water rates, and other household bills". In addition to increasing general public awareness, the firm D interviewee added "... some of our customers in the villages are continuously seeking ways to learn how to use mobile money. We have some customers in the villages asking us to teach them how to use their smartphones for money transfer".

The firm $\mathrm{C}$ interviewee also recognized the increasing public awareness of mobile money usage in Freetown. Specifically, he pointed out that "... today, our customers are more efficient with the use of mobile money, and even those who do not have a bank account are eager to open a bank account and learn how to do simply money transfer". He added "I sometimes even stand as a bank guarantor for some of my customers. The reason for this is because most fishmongers come to the market at 08:00 am and leave at 19:00, thus, [some fishmongers] have little time to visit the bank to deposit money into their deposit account for money transfer".

The firm B interviewee also expressed similar sentiments towards the increasing public awareness of mobile money. In this regard, the interviewee indicated that "... there has been a definite increase in Fintech products through the chain of mobile money in Sierra Leone, and Sierra Leoneans are embracing mobile money across all corners of the country". Also, he emphasized that "not only is the simplicity of mobile money key to the increasing public awareness, but also the rise of mobile phone usage among entrepreneurs and the low-income population is prominent".

Although Fintech in Sierra Leone is gaining more acceptance by the BOP population, certain practical difficulties present challenges for the Fintech sector to realize its full potential. One of the concerns expressed by our interviewees was regarding the traditional banks that are active in Fintech making alliances with mobile phone firms, whose sim card is used for payment. In some cases, the charges by some of the Fintech apps can be relatively high. Specifically, while drawing attention to the contrasting mobile money charges across banks, the firm D interviewee stressed 
that "...over the past three years, the high charges in some banks pose challenges ...... The government can tell you that it is significantly cheap, yet still, I am charged every time I made a transaction using mobile money". Other interviewees offered similar views, where they acknowledged increased financial inclusion but recognize that usage charges could still be further reduced. However, the situation has improved compared to previously when the only option was to use the traditional banks. This proved to be very restrictive to the BOP population segment and micro-entrepreneurs. The following figure 1 summarizes the key findings of this study.

\section{Insert figure 1 here}

\section{Discussion and Implications}

We undertake an exploratory multi-case study to analyze how Fintech has affected BOP entrepreneurs in Sierra Leone. Our findings suggest that the rise of Fintech has been very positive for BOP entrepreneurs as it offers convenience and access to financial services. Our findings support the existing literature (Kemuma et al., 2015; Baumüller, 2018; Thakor, 2020; Coffie et al., 2020) that Fintech applications such as mobile money have resulted in an ease of transactions and increased business for BOP entrepreneurs. Our interviewees reveal a specific BOP concern regarding safety. Cash handling can be difficult and risky for individuals in a BOP context. This includes challenges for entrepreneurs seeking access to banking services, as well as robbery and petty theft (Khiaonarong and Humphrey, 2019; Makina, 2019). Additionally, we contribute to literature on Fintech services and traditional banks by revealing that high charges in some banks pose challenges for Fintech inclusion and growth (Frost, 2020). This contribution is vital in postwar BOP economies like Sierra Leone since it demonstrates that regulatory factors can provide sustainable and better Fintech services to people (Arner et al., 2020; Frost, 2020).

All BOP entrepreneurs we interviewed stress that the rise of Fintech has resulted in less crime and robberies. It is interesting to observe that social value creation by Fintech for BOP entrepreneurs is visible in all interviews, along with social value creation by BOP entrepreneurs themselves. Hence, this paper supports previous findings where social value creation by BOP entrepreneurs has been highlighted as they provide vital products and services, in addition to the agricultural sector (Rahman et al., 2016, 2019; Heuer et al., 2020). 
Increased awareness of Fintech also emerges as an important issue, which contributes to social value creation. BOP entrepreneurs often must work longer hours (Sarkar, 2018). This means entrepreneurs do not have enough time to stand in bank queues to deposit cash or pay utility bills, resulting in time wasted and lost opportunities. The rise of Fintech in Sierra Leone has significantly contributed to time savings for entrepreneurs. It is evident from the interviews that both BOP entrepreneurs and their customers have benefited from FinTech. Both parties are keen to learn new ways of using mobile phones and related Fintech apps, which increases self-esteem and trust in financial services. Our finding also contributed to the extant literature on greater potential in countries with high smartphone market penetration (Arner et al., 2020) by revealing the importance of increasing access to high-end phones in Sierra Leone. Such a contribution, as we explored, helps BOP entrepreneurs by providing transactional security, convenience, and reducing physical cash robberies.

Our findings offer both theoretical, managerial, and policy implications. From a theoretical perspective, our study highlights the importance of context-specific theorization when analyzing BOP entrepreneurship and Fintech. For example, in some other setting, the possibility of safety from a street robbery may not appear to be part of social value creation by a technological development like Fintech. However, in a country like Sierra Leone, which has experienced both a civil war and Ebola outbreak, insecurity has been one of the biggest concerns expressed by BOP individuals. Hence, scholars need to incorporate contextual elements of risk, uncertainty, and volatility while theorizing on Fintech's application in BOP contexts. A key managerial implication relates to micro-firm entrepreneurs and information specific benefits. Fintech offers entrepreneurs the possibility to be in regular contact with customers and evaluate their purchasing patterns as well as emergent needs. Also, in a volatile context like Sierra Leone, Fintech offers BOP entrepreneurs a possibility to further develop technical skills. For example, apps learning can be used as a base for further skills development, where individuals can use similar information services for streamlining their supply chains and coordination with (informal) entrepreneurial network members. From a policy perspective, our study highlights the importance of regulating Fintech charges so that the affordability is increased, which would result in significantly more BOP entrepreneurs using these services. This will also be useful for the government, as well from a taxation point of view. At the same time, Fintech firms need to think about long term strategies such as market base expansion in the BOP sector. If policymakers offer appropriate incentives, 
this will encourage more competition in the domestic Fintech sector, lowering Fintech market entry barriers, resulting in more affordable and more utilized Fintech services.

Our paper does have a couple of limitations. One limitation relates to data collection (interviews) from entrepreneurs located only in the capital city, Freetown. It is quite likely that BOP entrepreneurs in other cities or rural locations (especially in sectors like smaller trading or agriculture) could have certain differences compared to Freetown entrepreneurs. Hence, future studies could undertake an in-depth study of micro enterprises' entrepreneurs in a specific sector like agriculture. Such a study would further enhance our theoretical and practical understanding and contribute to an important yet under-researched area of the urban-rural divide in BOP entrepreneurship dynamics.

Finally, our findings reveal that BOP consumers are keen to learn more about Fintech and other mobile applications from BOP entrepreneurs. This learning exchange between buyer and seller is an under-researched topic, and future studies should explore it in different empirical contexts. 


\section{REFERENCES}

Arslan.,A., Golgeci, I., Haapanen, L., Tarba, S., Cooper, C. and Degbey, W. Y. (2020), "Causerelated marketing, legitimacy and internationalization of professional service firms: a case study of a football talent scouting microfirms", International Journal Review, Vol. 37 No. 5, pp. 885899.

Alaassar, A., Mention, A-L. and Aas, T. H. (2020), "Exploring how social interactions influence regulators and innovators: the case of regulatory sandboxes", Technological Forecasting and Social Change, Vol. 160, 120257.

Alkhowaiter, W. A. (2020), "Digital payment and banking adoption research in Gulf countries: a systematic literature review", International Journal of Information, Vol. 53, 102102.

Alt, R., Beck, R. and Smits, M. T. (2018), "FinTech and the transformation of the financial industry", Electron Markets, Vol. 28, pp. 235-243.

Anderson, A.R. and Obeng, B.A. (2017), "Enterprise as socially situated in a rural poor fishing community", Journal of Rural Studies, Vol. 49, pp. 23-31.

Arner, D. W., Buckley, R. P., Zetzsche, D. A. and Veidt, R. (2020), "Sustainability, FinTech and Financial Inclusion”, European Business Organization Law Review, Vol. 21, pp. 7-35.

Arner, D. W., Barberis, J. N. and Buckley, R. P. (2015), "The evolution of fintech: a new postcrisis paradigm?", available at http://hdl.handle.net/10722/221450 (accessed 10 April 2021).

Ashenafi, B. F., Kingstone, M., Roelof, G., Emanuel, M. and Kettles, N. (2020), "The role of mobile money in financial inclusion in the SADC region: evidence using FinScope surveys", working paper, No. 03/2016, FinMark Trust, South Africa, 2016 December.

Asongu, S. A., Nwachukwu, J. and Orim, S-M. I. (2018), "Mobile phones, institutional quality and entrepreneurship in Sub-Saharan Africa", Technological Forecasting and Social Change, Vol. 131, pp. 183-203.

Baumüller, H. (2018), "The little we know: an exploratory literature review on the utility of mobile phone-enabled services for smallholder farmers", Journal of International Development, Vol. 30 No. 1, pp. 134-154.

Baxter, P. and Jack, S. (2008), "Qualitative case study methodology: study design and implementation for novice researchers", The Qualitative Report, Vol. 13 No. 4, pp. 544-559.

Beck, T., Senbet, L. and Simbanegavi, W. (2014), "Financial inclusion and innovation in Africa: an overview", Journal of African Economies, Vol. 24 No. 1, pp. i3-i11. 
Berger, A. N., Demsetz, R. S. and Strahan, P. (1999), "The consolidation of the financial services industry: causes, consequences, and implications for the future", Journal of Banking \& Finance, Vol. 23 No 2/4, pp. 135-194.

Birkinshaw, J., Brannen, Y. M. and Tung, L. R. (2011), "From a distance and generalizable to up close and grounded: reclaiming a place for qualitative methods in international business research", Journal of International Business Studies, Vol. 42 No. 5, pp. 574-581.

Boateng, R. and Sarpong, M. Y. P. (2019), “A literature review of mobile payments in Sub-Saharan Africa”, in Dwivedi, Y., Ayaburi, E., Boateng, R. and Effah, J. (Eds), ICT Unbounded, Social Impact of Bright ICT Adoption. TDIT 2019, IFIP Advances in Information and Communication Technology, Springer, Cham, Vol. 558, pp. 128-146.

Braun, V. and Clarke, V. (2008), "Using thematic analysis in psychology", Qualitative Research in Psychology, Vol. 3 No. 2, pp. 77-101.

Buchanan, B. and Cao, C. (2018), "Quo Vadis? A Comparison of the Fintech Revolution in China and the West," working paper, SWIFT Institute. Available online at https://swiftinstitute.org/wpcontent/uploads/2018/10/SIWP-2017-002-_Fntech_China_West_BuchCao_FINAL.pdf

Cazurra, C. A., Andersson, U., Brannen, Y. M., Nielsen, B. B. and Reuber, R. A. (2016), "From the editors. can I trust your findings? Ruling out alternative explanations in international business research," Journal of International Business Studies, Vol. 47, pp. 881-897.

Chandy, R. and Narasimhan, O. (2011), "How micro-entrepreneurs could change the world", Business Strategy Review, Vol. 22 No. 1, pp. 42-55.

Chen, M. A., Wu, Q. and Yang, B. (2019), "How valuable is fintech innovation?", The Review of Financial Studies, Vol 32 No. 5, pp. 2061-2106.

Chetty, S. (1996), "The case study method for research in small-and medium-sized firms", International Small Business Journal, Vol. 15 No. 1, pp, 73-85.

CIA (2020), "The world factbook: world trade facts", available at https://www.cia.gov/the-worldfactbook/references/world-travel-facts/ (Accessed 16 July 2020).

Coffie, C. P. K., Hongjiang, Z., Mensah, I. A., Kiconco, R. and Simon, A. E. O. (2020), "Determinants of FinTech payment services diffusion by SMEs in Sub-Saharan Africa: evidence from Ghana", Information Technology for Development, Vol. 27, No 3, pp. 539-560.

Collier, P., and Duponchel, M. (2013). "The economic legacy of civil war: firm-level evidence from Sierra Leone," Journal of Conflict Resolution, Vol. 57 No 1, pp. 65-88.

Da-Silva, L.A.P. (2018), "Fintech in EMEs: blessing or curse?", Panel remark presented at the CV Meeting of Central Bank Governors of CEMLA, 5 June 2018, Asuncion, Paraguay, available at https://www.bis.org/speeches/sp180620.pdf. 
Das, S. R. (2019), “The future of fintech”, Financial Management, Vol. 48 No. 4, pp. 981- 1007.

Das, G. G. and Drine, I. (2020), "Distance from the technology frontier: how could Africa catchup via socio-institutional factors and human capital?", Technological Forecasting and Social Change, Vol. 150, pp. 2-16.

De Silva, M., Khan, Z., Vorley, T. and Zeng, J. (2019), "Transcending the pyramid: opportunity co-creation for social innovation", Industrial Marketing Management, Vol. 89 No. 16, pp. 471486.

Demirguç-Kunt, A., Klapper, L., Singer, D., Ansar, S. and Hess, J. (2017), "Measuring financial inclusion and the fintech revolution", The Global Findex Database, World Bank Group, Washington, DC.

Dewan, S. M. (2010), "Past, present and future of m-banking research: a literature review", paper presented at the ACIS 2010 Proceedings. 84, 1-3 Dec 2010, Brisbane, Queensland, available at http://aisel.aisnet.org/acis2010/84 (accessed 9 April 2021).

Didenko, A. (2017), "Regulating fintech: lessons from Africa", San Diego International Law Journal, Vol. 19 No. 2, pp. 311-370.

Eicher, C. K. and Baker, D. C. (1982), "Research on agricultural development in Sub-Saharan Africa: a critical surbey", in Martin, L. E. (Ed), Survey of Agricultural Economics Literature, Michigan State University, Department of Agricultural, Food, and Resource Economics, available at http://ageconsearch.umn.edu/record/54071/files/idp1_w_cover.pdf

Eisenhardt, K. M. (1989), "Building theories from case study research", Academy of Management Review, Vol. 14 No. 4, pp. 532-550.

Eisenhardt, K. M. (2020), “Theorizing from cases: a commentary”, in Eden, L., Nielson, B. and Verbeke, A. (Eds), Research Methods in International Business, Palgrave Macmillan, Chan, pp. 221-227.

Financial Stability Board. (2017). "Artificial intelligence and machine learning financial services," available at https://www.fsb.org/wp-content/uploads/P011117.pdf (Accessed 14 July 2020).

Frost, J. (2020), "The economic forces driving fintech adoption across countries", BIS Working Papers No 838, Bank for International Settlements, Australia, 4 February 2020.

Ghosh, S. (2016), "Does mobile telephony spur growth? evidence from Indian states", Telecommunications Policy, Vol. 40 No. 10, pp. 1020-1031.

Gomber, P., Kauffman, R. J., Paker, C. and Weber, B. W. (2018), "On the fintech revolution: interpreting the forces of innovation, disruption and transformation in financial services", Journal of Management Information Systems, Vol. 35 No. 1, pp.220-265. 
GPFI (2016), "Global standard-setting bodies and financial inclusion: the evolving landscape", available at http://www.gpfi.org/publications/global-standard-setting-bodies-and-financialinclusion-evolving-landscape (Accessed 16 July 2020).

GSMA (2020), "The mobile economy", available at file:///C:/Users/sampk/OneDrive/Desktop/DE\%20B-Chapter/research-file-download.pdf (accessed 11 April 2021).

GSMA (2019), "The mobile economy Sub-Saharan Africa", available at https://www.gsma.com/mobileeconomy/sub-saharan-africa/ (Accessed 10 July 2020).

Gölgeci, I., Arslan, A., Dikova, D. and Gligor, D. M. (2020), "Resilient agility in volatile economies: institutional and organizational antecedents", Journal of Organizational Change Management, Vol. 33 No. 1, pp. 100-113.

Hall, J., Matos, S. V. and Martin, M. J. C. (2014), "Innovation pathways at the base of the pyramid: establishing technological legitimacy through social attributes", Technovation, Vol. 34 Nos. 5/6, pp. 284-294.

Hall, J., Matos, S., Sheehan, L. and Silvestre, B. (2012), "Entrepreneurship and innovation at the base of the pyramid: a recipe for inclusive growth or social exclusion?", Journal of Management Studies, Vol. 49 No. 4, pp. 785-812.

Heuer, M. A., Khalid, U. and Seuring, S. (2020), "Bottoms up: delivering sustainable value in the base of the pyramid", Business Strategy and the Environment, Vol. 29 No. 3, pp. 1605-1616.

Hilson, G. (2016), "Farming, small-scale mining and rural livelihoods in Sub-Saharan Africa: a critical overview", The Extractive Industries and Society, Vol. 3 No. 2, pp. 547-563.

Humphrey, D. B., Pulley, L. B. and Vesala, J. M. (1996), “Cash, paper, and electronic payments: a cross-country analysis", Journal of Money, Credit and Banking, Vol. 28 No. 4, pp. 914-939. https://doi.org/10.2307/2077928.

Kabbiri, R., Dora, M., Kumar, V., Elepu, G. and Gellynck, X. (2018), "Mobile phone adoption in agri-food sector: are famers in Sub-Saharan Africa connected?", Technological Forecasting and Social Change, Vol. 131, pp. 253-261.

Kamara, S. F. (2008), "Economic and social crises in Sierra Leone: the role of small-scale entrepreneurs in petty trading as a strategy for survival 1960-1996", Author House Publications: Central Milton Keynes, Bloomington, Indiana.

Kamran, S. and Uusitalo, O. (2019), "Banks' unfairness and the vulnerability of low-income unbanked consumers", Service Industries Journal, Vol. 39 No. 1, pp. 65-85.

Kemuma, J., Khayesi, M. and Nafukho, F. M. (2015), "Informal public transport in practice: matatu entrepreneurship", Ashgate Publishing, Farnham. 
Khalik, M. and Lopez-Gomez, S. (2018), "Understanding social business and wellbeing at the BoP: the inspiring Case of Algramo", Sanchez-Barrios, L. J. and Gomez-Nunez, L. (Ed.s), Evolving Entrepreneurial Strategies for Self-Sustainability in Vulnerable American Communities, IGI Global, pp. 305-323.

Khiaonarong, T. and Humphrey, D. (2019), "Cash use across countries and the demand for central bank digital currency", working paper (E41E42E58E59), IMF, March 2019, available at https://www.imf.org/en/Publications/WP/Issues/2019/03/01/Cash-Use-Across-Countries-andthe-Demand-for-Central-Bank-Digital-Currency-46617 (Accessed 8 July 2020).

Kikulwe, E. M., Fischer, E. and Qaim, M. (2014), "Mobile money, smallholder's farmers, and household welfare in Kenya", Plos One, Vol. 9 No. 10, pp. 1-3.

Kimmitt, J., Muñoz, P. and Newbery, R. (2019), "Poverty and the varieties of entrepreneurship in the pursuit of prosperity", Journal of Business Venturing, Vol. 35 No. 4, pp. 2-18.

Koomson, I., Bukari, C. and Villano, R. A. (2021), "Mobile money adoption and response to idiosyncratic shocks: empirics from five selected countries in Sub-Saharan Africa", Technological Forecasting and Social Change, Vol. 167, p. 120728.

Lee, T. W. and Lee, T. (1999), "Using qualitative methods in organizational research", Sage Publications, Thousand Oaks, CA.

Lee, I. and Shin, Y. J. (2018), "Fintech: ecosystem, business models, investment decisions, and challenges", Business Horizons, Vol. 61 No 1, pp. 35-46.

Leposky, T., Arslan, A. and Dikova, D. (2020), "Value co-creation in multinational enterprises' services marketing at the bottom-of-the-pyramid markets", in Marinov, M., Marinova, S., Larino, J. and Leposky, T. (Ed.s), International Business and Emerging Economy Firms, Palgrave Macmillan, Cham, Vol. 1, pp. 89-116.

Liu, J., Li, X. and Wang, S. (2020), "What have we learnt from 10 years of fintech research? a scientometric analysis", Technological Forecasting and Social Change, Vol. 155, pp. 2-12.

Lyson, T. A. (2012), "Civic agriculture: reconnecting farm, food, and community", Tufts University Press, Medford, MA.

Maino, R., Massara, A., Perez- Saiz, H. and Sharma, P. (2019), "Fintech in Sub-Saharan African countries: a game changer?", International Monetary Fund, available at https://www.imf.org/ /media/Files/Publications/DP/2019/English/FTSSACEA.ashx

(Accessed 16 July 2020).

Makina, D. (2019), "Extending financial inclusion in Africa”, Academic Press, Elsevier, London.

Manyika, J., Lund, S., Singer, M., White, O. and Berry, C. (2016), "Digital finance for all: powering inclusive growth in emerging economies", McKinsey Global Institute, Amsterdam, 
available

https://www.mckinsey.com/ /media/McKinsey/Featured\%20Insights/Employment\%20and\%20

Growth/How\%20digital\%20finance\%20could\%20boost $\% 20$ growth\%20in\%20emerging\%20eco

nomies/MG-Digital-Finance-For-All-Full-report-September-2016.pdf. (Accessed 10 July 2020)

Maurer, B. (2012), "Mobile money: communication, consumption and change in the payments space", Journal of Development Studies, Vol. 48 No. 5, pp. 589-604.

Mothobi, O. and Grzybowski, L. (2017), "Infrastructure deficiencies and adoption of mobile money in Sub-Saharan Africa”, Information Economics and Policy, Vol. 40, pp. 71-79.

OECD-FAO. (2016), "Agriculture in Sub-Saharan Africa: prospects and challenges for the next decade". OECD Publishing, Paris, available at https://www.oecd-ilibrary.org/agriculture-andfood/oecd-fao-agricultural-outlook-2016-2025/agriculture-in-sub-saharan-africa-prospects-andchallenges-for-the-next-decade_agr_outlook-2016-5-en (Accessed 16 July 2020).

Onsongo, E. (2019), "Institutional entrepreneurship and social innovation at the base of the pyramid: the case of M-Pesa in Kenya”, Industry and Innovation, Vol. 26 No. 4, pp. 369-390.

Palmié, M., Wincent, J., Parida, V. and Caglar, U. (2020), “The evolution of the financial technology ecosystem: an introduction and agenda for future research on disruptive innovations in ecosystems", Technological Forecasting and Social Change, Vol. 151, pp. 2-10.

Patton, M. Q. (2002), “Qualitative research and evaluation methods”, Sage, Thousand Oaks, CA.

Rahman, S. A., Ahmad, N. H. and Taghizadeh, S. K. (2016), "Entrepreneurial competencies of BoP entrepreneurs in Bangladesh to achieve business success", Journal of General Management, Vol. 42 No. 1, pp. 45-63.

Rahman, S. A., Amran, A., Ahmad, N. H. and Taghizadeh, S. K. (2019), "The contrasting role of government and NGO support towards the entrepreneurs at base of the pyramid and effect on subjective wellbeing", Journal of Small Business \& Entrepreneurship, Vol. 31 No. 4, pp. 269-295.

Reuber, R. A., Dimitratos, P. and Kuivalainen, O. (2017), "Beyond categorization: new directions for theory development about entrepreneurial internationalization", Journal of International Business Studies, Vol. 48 No. 4, pp. 411-422.

Romānova, I. and Kudinska, M. (2016), "Banking and fintech: a challenge or opportunity?", Contemporary Issues in Finance: Current Challenges from Across Europe (Contemporary Studies in Economic and Financial Analysis), Vol. 98, pp. 21-35.

Sanchez-Barrios, L., Giraldo, M., Khalik, M. and Manjarres, R. (2015), "Services for the underserved: unintended well-being", The Service Industries Journal, Vol. 35 Nos 15/16, pp. 883897. 
Sakar, S. (2018), "Grassroots entrepreneurs and social change at the bottom of the pyramid: the role of bricolage", Entrepreneurship \& Regional Development, Vol. 30 No 3/4, pp. 421-449.

Shaikh, A. A. and Karjaluoto, H. (2015), "Mobile banking adoption: a literature review", Telematics and Informatics, Vol. 32 No 1, pp. 129-142.

Statista, (2020), Global fintech report, Statista Digital Market Outlook, Germany, available at https://www.statista.com/study/44525/fintech-report/ (Accessed 27 July 2020).

Stenbacka, C. (2001), "Qualitative research requires quality concepts of its own”. Management Decision, Vol. 39 No. 7, pp. 551-556.

Surie, G. (2017), "Creating the innovation ecosystem for renewable energy via social entrepreneurship: Insights from India”, Technological Forecasting and Social Change, Vol. 121, pp. 184-195.

Sutter, C., Bruton, G. D. and Chen, J. (2019), "Entrepreneurship as a solution to extreme poverty: a review and future research directions", Journal of Business Venturing, Vol. 34 No. 1, pp. 197214.

Tam, C. and Oliveira, T. (2017), "Literature review of mobile banking and individual performance", International Journal of Banking Marketing, Vol. 35 No. 7, pp. 1044-1067.

Teja, A. (2017), "Indonesian Fintech Business: New Innovations or Foster and Collaborate in Business Ecosystems?", The Asian Journal of Technology Management, Vol. 10 No. 1, pp. 10-18.

Thakor, A. V. (2020), "Fintech and banking: what do we know?", Journal of Financial Intermediation, Vol. 41, p. 100858.

Vives, X. (2017), “The impact of fintech on banking”, Calzolari, G. and Franco, A. (Ed.s); Fintech and banking. friends or foes? Europeye srl, Roma, pp. 97-105.

Watkins, T. A., DiLeo, P., Kanze, A. and Lieberman, L. (2017), "Fintech in microfinance: in search of the high-tech high-touch unicorn?", Center for financial inclusion, available at https://www.centerforfinancialinclusion.org/Fintech-in-microfinance-in-search-of-the-high-techhigh-touch-unicorn (accessed 16 July 2020).

Welsh, R. (1997), "Vertical coordination, producer response, and the locus of control over agricultural production decisions", Barham, E. and Hubbell, B. (Eds), Rural Strategy, Wiley, pp. 491-507.

Yao, M., Di, H., Zheng, X. and Xu, X. (2018), "Impact of payment technology innovations on the traditional financial industry: a focus on China", Technological Forecasting and Social Change, Vol. 135, pp. 199-207. 
Yermack, D. (2018), "Fintech in Sub-Saharan Africa: what has worked well, and what hasn't", NBER working paper (No. W25007), SSRN, Massachusetts, MA, September 2018. Available online at https://www.nber.org/system/files/working_papers/w25007/w25007.pdf.

Yousafzai, S. Y. (2012), "A literature review of the theoretical models of internet banking adoption at the individual level", Journal of Financial Service Marketing, Vol. 17, pp. 215-226.

Zetzsche, D. A., Arner, D. W., Buckley, R. P., \& Weber, R. H. (2019). The future of data-driven finance and RegTech: Lessons from EU big bang II. Working paper 
Table 1: Case firms and Interviewees

\begin{tabular}{|c|c|c|c|c|c|}
\hline Firms & Industry & $\begin{array}{c}\text { Firm Age } \\
\text { (Years) }\end{array}$ & $\begin{array}{c}\text { No. of } \\
\text { employees }\end{array}$ & Interviewee & Gender \\
\hline A & Manufacturing & 5 & 6 & Owner & Female \\
\hline B & Cosmetics & 6 & 2 & Owner & Male \\
\hline C & Fishing & 5 & 5 & Owner & Male \\
\hline D & Agriculture & 8 & 8 & Owner & Male \\
\hline SLFINTECH & Industry Body & 4 & 8 & $\begin{array}{c}\text { 2 managerial } \\
\text { representatives }\end{array}$ & Both male \\
\hline
\end{tabular}

Figure 1: Summary of the Study Findings

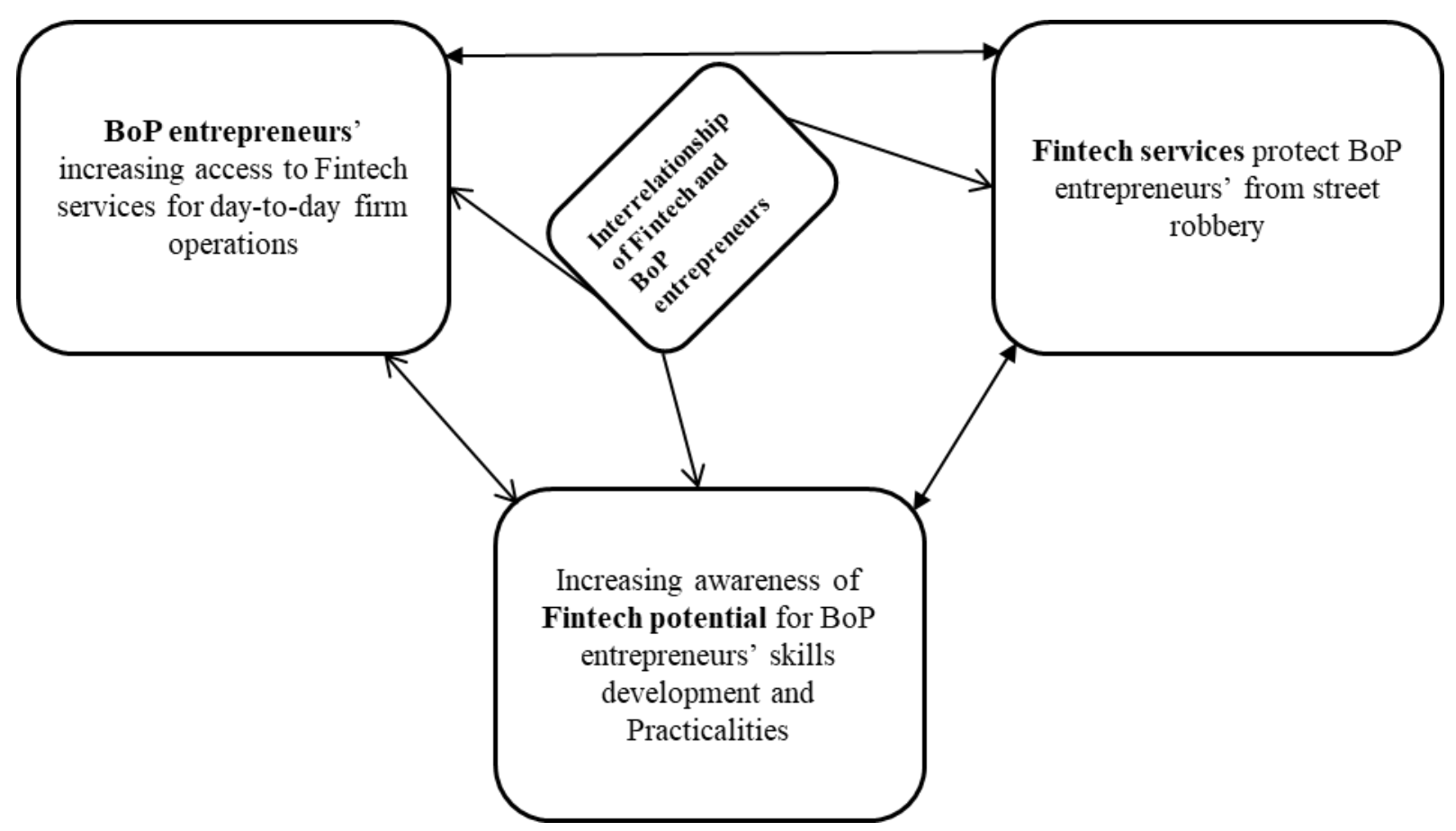

